\title{
THE MODERATING EFFECT OF WORK STRESS ON THE RELATIONSHIPS BETWEEN DIMENSIONS OF LEADER MEMBER EXCHANGE AND JOB SATISFACTION
}

\author{
*M.Gökhan BİTMISŞ \\ **Azize ERGENELI \\ *Gazi University, Turkey \\ **Hacettepe University, Turkey
}

\begin{abstract}
This study investigated the moderating effect of work stress on the relationships between dimensions of leader member exchange (LMX) and job satisfaction. 490 investment consultants were used to test our hypotheses via hierarchical moderated regression analyses. Our results revealed that work stress played moderation role on the relationships between contribution and loyalty dimensions of LMX and job satisfaction. However, work stress was not a moderator for affect and professional respect dimensions. Further, we found that all dimensions of LMX were positively related to job satisfaction. Some suggestions for future research are offered.
\end{abstract}

Keywords: leader member exchange; work stress; job satisfaction

\section{INTRODUCTION}

The quality of the relationships between leader and his or her followers, which is studied by the help of leader-member exchange (LMX) theory, has been the focus of practitioners and academics since the quality of leader-member exchange within the business environment can affect the success or failure of the today's competitive organizations. Leaders differentiate in their treatment of subordinates (Dansereau, Graen, \& Haga, 1975). Namely, a leader establishes high-quality exchanges with some members while low-quality exchanges with others. These exchanges result with many important outcomes such as job satisfaction (Graen et al., 1982a; Wilhelm, Herd \& Steiner, 1993; Schyns \& Croon, 2006), organizational commitment (Nystrom, 1990), organizational citizenship behavior (Scandura, Graen, \& Novak, 1986), empowerment (Keller \& Dansereau, 1995), innovation (Basu, 1991), increased team effectiveness (Boies \& Howell, 2006), decreased turnover (Graen, Liden, \& Hoel, 1982b) and decreased stress level (Snyder \& Bruning, 1985; Lagace et al., 1993; Culbertson, et. al, 2010). Therefore, the exchanges between leader and subordinates are extremely important. Research showed that those who remain in their jobs, working for poor bosses, have lower job satisfaction, lower commitment and higher psychological distress (Tepper, 2000).

Although the concept of LMX and its effects on job satisfaction have been studied by many researchers, the effect of work-related stress on the relationship between the dimensions of LMX and job satisfaction seems to be neglected in the literature. Therefore, the ultimate aim of this study is to explore the moderating effect of work stress on the relationships between the dimensions of leadermember exchange and job satisfaction for intermediary institutions.

The article proceeds in the following order. First, we briefly review the literature regarding leader member exchange, work stress and job satisfaction. Then, we explain in detail the data collection method, analytical procedures, and hypotheses testing. Finally, the results will be discussed. 


\section{LITERATURE REVIEW}

The Leader-Member Exchange (LMX) theory that is emerged in the 1970s has evolved substantially (Graen and Cashman, 1975; Dansereau et al., 1975; Graen, 1976; Graen and Scandura, 1987; Graen and Uhl-Bien, 1991; Graen et al., 1982a,b). Leader-member exchange theory handles leadership as a process of interaction between leader and follower. Namely, LMX suggests that leader and subordinates are involved in an exchange relationship. Leaders establish high quality exchanges with a few subordinates, who are seen as falling in the in-group or leader's inner circle. In the context of this in-group, leaders show influence and support beyond what is specified in formal descriptions, and the subordinate is given more autonomy and responsibility. However, low quality relationships are thought to be limited to the exchanges that take place according to the employment contract (Sparrowe and Liden, 1997).

Multidimensionality of the LMX is discussed in the literature. Four dimensions that compose the LMX relationships are affect, contribution, loyalty, and professional respect (Dienesch \& Liden, 1986; Liden \& Maslyn, 1998). Affect means the mutual affection members of the dyad have for each other based primarily on interpersonal attraction rather than work or professional values (Dienesch \& Liden, 1986). Contribution dimension defined as the perception of amount, direction and, quality of work oriented activity each member puts toward the mutual goals of dyad (Dienesch \& Liden, 1986). Loyalty component of LMX refers to the extent to which both leader and member support one another's goals, actions, and personal character across situations (Dienesch \& Liden, 1986; Liden \& Maslyn, 1998). Final dimension, professional respect, refers to the perception of the degree to which each member of the dyad has built a reputation, within and/or outside the organization, of excelling at his or her line of work (Liden \& Maslyn, 1998).

LMX plays an important role in shaping employee attitudes such as job satisfaction (Graen et al., 1982a; Wilhelm, Herd \& Steiner, 1993; Schyns \& Croon, 2006) and stress level of subordinates (Snyder \& Bruning, 1985; Lagace et al., 1993; Culbertson, et. al, 2010). Consistent support has been found for a positive association between LMX and overall job satisfaction (Major et al., 1995; Seers \& Graen, 1984). The members who have high quality LMX relationships are often given some additional responsibilities, autonomy, and have the opportunity of communicating with their supervisor better which increases the job satisfaction of the subordinates. On the other hand, the subordinates in low quality LMX relationships receive less time and interest from their supervisors but have higher levels of supervisor control and direction which causes work related stress and dissatisfaction.

Liden and Maslyn (1998) found that subordinate's affect, loyalty and professional respect, but not contribution, accounted for unique variance in satisfaction with supervisor. Mardanov, et al. (2007) also investigated the relationships between the dimensions of LMX on the job satisfaction. They found positive relationships between affect, loyalty and professional respect dimensions of LMX and job satisfaction.

On the other hand, work stress, which affects interpersonal relationships in the organizations, is another important factor when determining the LMX-job satisfaction relationship. Work-related stress has many causes including excessive time pressure or inflexible working hours, heavy work load, tight deadlines, lack of autonomy, too much or too little responsibility, insufficient skills for the job, oversupervision, inadequate working environment, few promotional opportunities, poor relationships with supervisors and colleagues. In low quality LMX relationships subordinates receive less time and interest from their supervisors but they are more directed and tightly controlled which result in workrelated stress and dissatisfaction. Some study results revealed that there is a negative relationship between high quality LMX relationship and work-related stress (Snyder \& Bruning, 1985; Lagace et al., 1993). Thomas and Lankau (2009) reported that LMX was positively associated with organizational socialization, which in turn negatively related to work-related stress.

Although many study results yielded some strong positive relationships between the dimensions of LMX and job satisfaction and negative effect of LMX on work-related stress, it seems that little attention has been given to the question of how work-related stress moderates the dimensions of LMX -job satisfaction relationships. Therefore, the study hypotheses are as follows: 
$H_{1}$ : There is a positive relationship between the affect dimension of leader-member exchange and job satisfaction.

$\mathrm{H}_{2}$ : Work stress moderates the relationship between the affect dimension of leader-member exchange and job satisfaction in such a way that the relationship is stronger when work stress is low than when it is high.

$H_{3}$ : There is a positive relationship between the loyalty dimension of leader-member exchange and job satisfaction.

$H_{4}$ : Work stress moderates the relationship between the loyalty dimension of leader-member exchange and job satisfaction in such a way that the relationship is stronger when work stress is low than when it is high.

$H_{5}:$ There is a positive relationship between the contribution dimension of leader-member exchange and job satisfaction.

$H_{6}$ : Work stress moderates the relationship between the contribution dimension of leader-member exchange and job satisfaction in such a way that the relationship is stronger when work stress is low than when it is high.

$H_{7}$ : There is a positive relationship between the professional respect dimension of leader-member exchange and job satisfaction.

$H_{8}$ : Work stress moderates the relationship between the professional respect dimension of leadermember exchange and job satisfaction in such a way that the relationship is stronger when work stress is low than when it is high.

\section{METHOD}

\section{Sample and Data Collection Procedure}

Data obtained via questionnaires in our research. Survey questionnaires were distributed to a randomly selected group of investment consultants, who work for non-bank financial intermediaries in Turkey. We reached 550 questionnaires in total. Some of them were excluded due to the excessive missing data, resulting 490 useable questionnaires. The return rate of the questionnaires was $84 \%$. The sample was composed of $58 \%$ male and $42 \%$ women. The average age of our respondents was 35.33 .

\section{Measures}

\section{Leader-member exchange}

Liden and Maslyn's (1998) 12-item multidimensional LMX scale has been used in this research in order to measure exchange quality. LMX scale is measured using five-point Likert scale with anchors ranging from strongly disagree $(=1)$ to strongly agree $(=5)$. A sample item included "My supervisor would defend me to others in the organization if I made an honest mistake". The Cronbach's Alpha coefficients were respectively $0.92,0.88,0.80,0.92$, and 0.93 for affect, loyalty, contribution, professional respect dimensions and overall LMX, which refer to the high consistency of the scale.

Further, we conducted confirmatory factor analysis (CFA) in order to validate the factor structure of LMX. Leader-member exchange was modeled as a second-order factor composed of four subscales such as affect, loyalty, contribution, and professional respect. Results showed that a 4-factor model with a second order LMX yielded a good fit to the data. (GFI=0.93; NFI=0.96; IFI=0.97; CFI $=0.97$; RMSEA $=0.08$ ). The factor loadings, which gauge affect, loyalty, contribution, professional respect and second order LMX, was higher than 0.50 and they were significant $(p<0.05)$. Therefore, we validated four-factor model (affect, loyalty, contribution, and professional respect) with a second order factor (LMX). 


\section{Job Satisfaction}

Job satisfaction was assessed by using Global Job Satisfaction scale, which was originally developed by Quinn and Shepard (1974) and subsequently modified by Pond and Geyer (1991). Scale's response format was also a 5-point Likert scale. Sample questions include: "In general: how much do you like your job?" (Responses range from $1=$ not at all to $5=$ great deal.) and "How does this job compare with your ideal job (job you would most like to have) ?" (Responses range from 1 = very far from ideal to $5=$ very close to ideal.) The Cronbach's Alpha coefficient was 0.92 .

\section{Work Stress}

House and Rizzo's Job-Induced Tension (1972a,b) scale, which is composed of seven items was used to measure the work stress. Response options ranged from 1 (strongly disagree) to 5 (strongly agree). Sample items included 'I work under a great deal of tension', 'I have felt fidgety or nervous as a result of my job', and 'My job tends to directly affect my health'. The Cronbach's alpha for this measure was 0.88 .

\section{ANALYSES AND RESULTS}

We tested our hypotheses by using hierarchical moderated regression analyses and correlation analysis. We used Aiken \& West's (1991) methodology in order to measure moderation effect of work stress. First, we entered the mean centered affect, loyalty, contribution, and professional respect dimensions of LMX and the mean centered work stress term to the regression models in order to reduce multicollinearity. Then we entered the interaction term formed by multiplying the mean centered dimensions of LMX and work stress term (Aiken \& West, 1991). The moderator hypotheses are supported if the interaction terms are significant. Further, we should check whether the increase in $\mathrm{R}^{2}$ is also statistically significant or not, which would bring more evidence in favor of the moderator effect.

Table 1 provides the means, standard deviations, and Pearson correlations for the measures of affect, loyalty, contribution, professional respect, work stress, and job satisfaction. The correlations show that job satisfaction was positively correlated with affect $(.58, \mathrm{p}<.01)$, loyalty $(.43, \mathrm{p}<.01)$, contribution $(.52, \mathrm{p}<.01)$, and professional respect $(.57, \mathrm{p}<.01)$. All the correlations are statistically significant. Affect dimension of leader-member exchange was somewhat more highly correlated with the job satisfaction relative to other dimensions. Further, there was statistically significant and negative association between work stress and job satisfaction $(-.44, \mathrm{p}<.01)$.

Table 1 Summary Statistics and Correlations

\begin{tabular}{|c|c|c|c|c|c|c|c|c|c|}
\hline & & $\mathbf{M}$ & SD & 1 & 2 & 3 & 4 & 5 & 6 \\
\hline 1 & Affect & 3.91 & .82 & --- & & & & & \\
\hline 2 & Loyalty & 3.69 & .84 & $0.64^{* *}$ & --- & & & & \\
\hline 3 & Contribution & 3.98 & .78 & $0.62^{* *}$ & $0.62^{* *}$ & --- & & & \\
\hline 4 & Professional respect & 3.94 & .91 & $0.71^{* *}$ & $0.53^{* *}$ & $0.63^{* *}$ & --- & & \\
\hline 5 & Work stress & 2.88 & .90 & $-0.36^{* *}$ & $-0.29^{* *}$ & $-0.29^{* *}$ & $-0.28^{* *}$ & --- & \\
\hline 6 & Job Satisfaction & 3.60 & .86 & $0.58^{* *}$ & $0.43^{* *}$ & $0.52^{* *}$ & $0.57^{* *}$ & $-0.44^{* *}$ & --- \\
\hline
\end{tabular}

Note: $\quad * * . \mathrm{p}<0.01$

Table 2 presents the results of our hierarchical moderated regression analyses in order to test the moderating effect of work stress on the relationships between the dimensions of LMX and job satisfaction. Results show that affect is positively and significantly related to job satisfaction $(\beta=$ $0.46, \mathrm{p}<.001)$. However, work stress is negatively and significantly related to job satisfaction $(\beta=-$ $0.27, \mathrm{p}<.001)$. Therefore, we accept Hypothesis 1 . The interaction terms were entered in step 2 . We see that the affect $\mathrm{x}$ work stress interaction was not significantly related to job satisfaction. Namely, work stress does not moderate the relationship between affect and job satisfaction. Thus, we reject Hypothesis 2. 


\section{Table 2 Hierarchical Moderated Regression Analyses to Test the Moderating Effect of Work Stress on the Relationship between Affect, Loyalty, Contribution, and Professional Respect Dimensions of Leader Member Exchange and Job Satisfaction}

\begin{tabular}{|c|c|c|}
\hline D.V. = Job satisfaction & Step 1 & Step 2 \\
\hline Affect & $0.49^{* *}$ & $0.46^{* *}$ \\
\hline Work stress & $-0.26 * *$ & $-0.27 * *$ \\
\hline Affect $x$ Work stress & & 0.07 \\
\hline $\mathrm{F}$ & $167.90 * *$ & $113.86^{* *}$ \\
\hline Total $\mathrm{R}^{2}$ & $0.40 * *$ & 0.41 \\
\hline Change in $\mathrm{R}^{2}$ & & 0.00 \\
\hline Loyalty & $0.33^{* *}$ & $0.31 * *$ \\
\hline Work stress & $-0.34 * *$ & $-0.35 * *$ \\
\hline Loyalty x Work stress & & $0.11 *$ \\
\hline $\mathrm{F}$ & $102.27 * *$ & $72.04 * *$ \\
\hline Total $\mathrm{R}^{2}$ & $0.29 * *$ & $0.30 *$ \\
\hline Change in $\mathrm{R}^{2}$ & & $0.01 *$ \\
\hline Contribution & $0.43^{* *}$ & $0.41 * *$ \\
\hline Work stress & $-0.31 * *$ & $-0.32 * *$ \\
\hline Contribution $\mathrm{x}$ Work stress & & $0.10^{*}$ \\
\hline $\mathrm{F}$ & $140.42 * *$ & $97.42 * *$ \\
\hline Total $\mathrm{R}^{2}$ & $0.36^{* *}$ & $0.37 *$ \\
\hline Change in $\mathrm{R}^{2}$ & & $0.01 *$ \\
\hline Professional respect & $0.48^{* *}$ & $0.47 * *$ \\
\hline Work stress & $-0.30 * *$ & $-0.30 * *$ \\
\hline Professional respect $\mathrm{x}$ Work stress & & 0.04 \\
\hline $\mathrm{F}$ & $169.39 * *$ & $113.36^{* *}$ \\
\hline Total $\mathrm{R}^{2}$ & $0.41 * *$ & 0.41 \\
\hline Change in $\mathrm{R}^{2}$ & & 0.00 \\
\hline
\end{tabular}

Note: Standardized coefficients are provided

$* \mathrm{p}<.05$

$* * \mathrm{p}<.00$

Results also show that loyalty is positively and significantly related to job satisfaction $(\beta=0.31, \mathrm{p}$ $<.001)$. This means that high scores of loyalty will lead to the high levels of job satisfaction. Thus, we accept Hypothesis 3. We also see that the loyalty $\mathrm{x}$ work stress interaction was significantly related to job satisfaction $(\beta=0.11, \mathrm{p}<.05)$. Further, the increase in $\mathrm{R}^{2}$ is also statistically significant $(\Delta$ $\mathrm{R}^{2}=0.01, \mathrm{p}<.05$ ), which would bring more evidence in favor of the moderator effect of work stress on the relationship between loyalty and job satisfaction. Figure 1 provides a graphical representation of the loyalty $x$ work stress interaction with job satisfaction as the outcome. As seen in this figure, the greatest rate of change for the job satisfaction occurred for those respondents who reported high stress level. Conversely, there was little change in the job satisfaction line slope for those respondents who reported low stress level. Additionally, the positive relationship between loyalty and job satisfaction was stronger when work stress was higher. Therefore, we partially accept Hypothesis 4 .

Table 2 depicts that there is positive association between contribution and job satisfaction $(\beta=0.41, \mathrm{p}$ $<.001)$. Thus, we accept Hypothesis 5. If we analyze the interaction term, which is contribution $\mathrm{x}$ work stress, it can be seen that the contribution $\mathrm{x}$ work stress interaction was significantly related to job satisfaction $(\beta=0.10, p<.05)$. Also, the increase in $R^{2}$ is statistically significant $\left(\Delta R^{2}=0.01\right.$, $\mathrm{p}<.05)$. Therefore, we have enough support for the moderator role of work stress on the relationship between contribution and job satisfaction. Figure 2 shows a graphical illustration of the contribution $\mathrm{x}$ 
work stress interaction with job satisfaction as the dependant variable. The graph explains that the greatest rate of change for the job satisfaction occurred for those respondents who reported high stress level. Moreover, the positive relationship between contribution and job satisfaction was stronger when work stress was higher. Thus, we partially accept Hypothesis 6.

\section{Figure 1: Interaction between Loyalty and Work Stress Predicting Job Satisfaction}

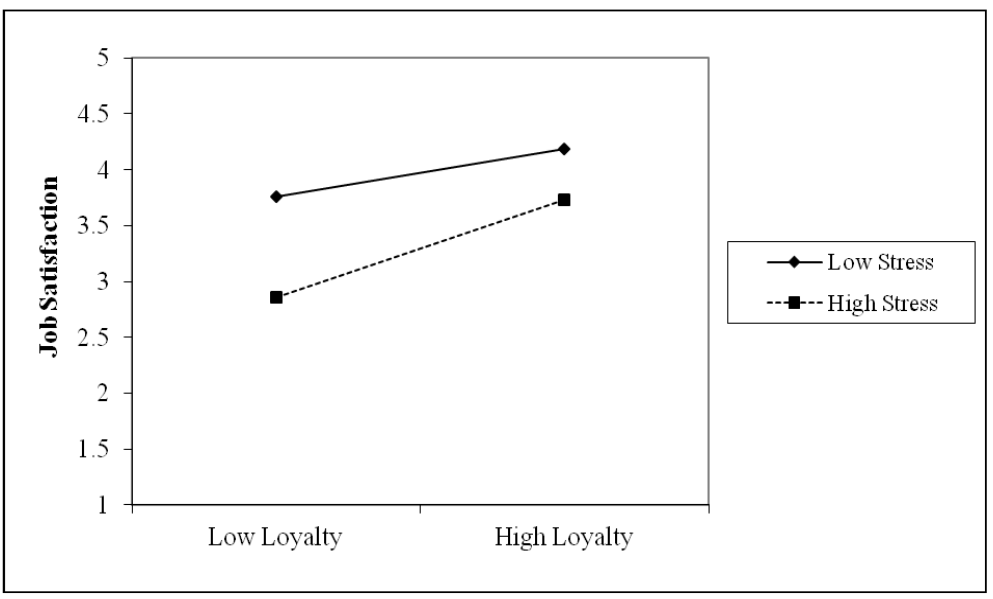

Table 2 also reveals that professional respect is positively and significantly related to job satisfaction $(\beta=0.47, p<.001)$. Therefore, we support Hypothesis 7 . However, we see that the professional respect $\mathrm{x}$ work stress interaction was not significantly related to job satisfaction. In other words, work stress does not moderate the relationship between professional respect and job satisfaction. Thus, we reject Hypothesis 8 .

\section{Figure 2: Interaction between Contribution and Work Stress Predicting Job Satisfaction}

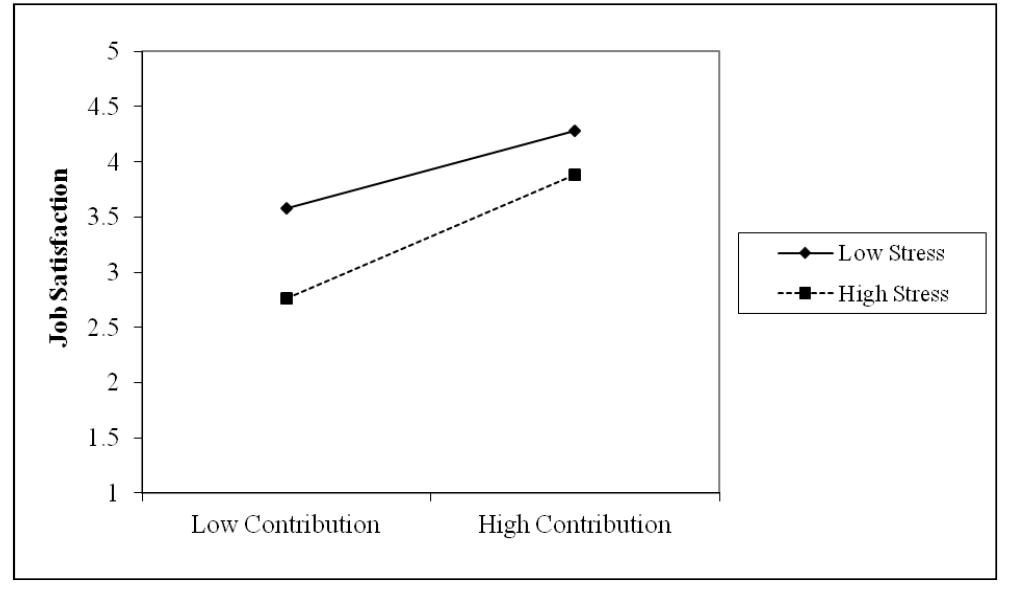

\section{DISCUSSION}

This study investigated the moderating effect of work stress on the relationships between affect, loyalty, contribution, professional respect dimensions of LMX and job satisfaction. Results show that affect, loyalty, and professional respect dimensions of LMX are positively related to the job satisfaction. These results are consistent with the findings from Liden and Maslyn (1998) and Mardanov, et al. (2007). However, we also found positive association between contribution and job satisfaction. Moreover, although affect and professional respect dimensions of LMX are strongly related to the job satisfaction, the work stress does not play a moderation role on these relationships. This result is in congruence with Liden and Maslyn (1998) and Mardanov, et al. (2007) study results in which affect and professional respect dimensions found to be directly related to the job satisfaction 
level of subordinates. On the other hand, the results of this study also reveal that work stress moderates the relationships between the loyalty and contribution dimensions of LMX and job satisfaction. Specifically, the relationships between loyalty and contribution dimensions of LMX and job satisfaction are become stronger when work stress level of subordinates increase. In other words, under high levels of work-related stress conditions, the relationships between job satisfaction of subordinates and their belief about supervisors' support to attain their goals and perceptions about the amount and quality of work oriented activity they receive from their supervisors will be stronger.

This result is quite meaningful when one considers the sample of this research, namely investment consultants. The job description of investment consultants includes contribution to the growth of the company funding portfolio through the development of relationships with new and existing customers, the accurate and timely processing of transactions, and the provision of quality customer service. Therefore, as those consultants are expected to be able to work well under pressure and in high volume work-flow environment, it is understandable that mutual support one another's goals and the amount of afford put towards the mutual goals of dyad becomes important. Thus, as it is inevitable to avoid work-related stress for investment consultants, their managers should pay attention on the contribution and loyalty dimensions of LMX in order to make them more satisfied with their jobs under high levels of work stress.

Although the findings from this study make a unique contribution to both the LMX and job satisfaction research streams, the primary contribution of our research is the joint effect of variables, as work stress moderates the dimensions of LMX-job satisfaction associations. This study should be replicated for other samples as our respondents came from financial intermediary institutions, which may have unique characteristics not found in other organizations. Additionally, we used a crosssectional design makes it difficult to determine the direction of causality among the study variables, and thus cause-effect relationships should not be inferred from our findings. We hope future studies with longitudinal data will extend our findings. 


\section{REFERENCES}

Aiken, L. S., \& West, S. G. (1991). Multiple regression: Testing and interpreting interactions. Newbury Park, CA: Sage

Basu, R. (1991). An empirical examination of leader-member exchange and transformational leadership as predictors of innovation behavior. Unpublished Ph.D. dissertation,Department of Management, Purdue University.

Boies, K., \& Howell, J. M. (2006). Leader-member exchange in teams: An examination of the interaction between relationship differentiation and mean LMX in explaining team-level outcomes. Leadership Quarterly, 17, 246-247.

Culbertson, S. S., Huffman, A. H., \& Alden-Anderson, R. (2010). Leader-member exchange and work -family interactions: The mediating role of self-reported challenge- and hindrance- related stress. Journal of Psychology: Interdisciplinary and Applied, 144, 15-36

Dansereau, F., Graen, G., \& Haga, W. J. (1975). A vertical dyad approach to leadership within formal organizations. Organizational Behavior and Human Performance, 13, p.46-78.

Dienesch, R. M., \& Liden, R. C. (1986). Leader-member exchange model of leadership: A critique and further development. Academy Management Review, 11, 618-634.

Graen, G.B., Novak, M., \& Sommerkamp, P. (1982a). The effects of leader-member exchange and job design on productivity and satisfaction: Testing a dual attachment model. Organizational Behavior and Human Performance, 30, p.109-131.

Graen, G. B., Liden, R. C., \& Hoel, W. (1982b). Role of leadership in the employee withdrawal process. Journal of Applied Psychology, 67, 868-872.

Graen, G.B. (1976). Role-making process within complex organizations. In Dunnete, M.D. (ed.), Handbook of Industrial and Organizational Psychology. Chicago: Rand McNally, pp 1201-1245

Graen, G.B., \& Cashman, J.F. (1975). A role-making model in formal organizations: A development approach. In Hunt, J.G., Larson, L.L. (eds.), Leadership Frontiers. Kent, Ohio: Kent State University Press, pp 143-165

Graen, G.B., \& Scandura, T. (1987). Toward a psychology of dyadic organizing. In Staw, B., Cumming, L.L. (eds.), Research in Organizational Behavior, Vol. 9.. Greenwich, Connecticut: JAI, pp $175-208$.

Graen, G.B., \& Uhl-Bien, M. (1991). Partnership-making applies equally well to teammate-sponsor, teammate-competence network, and teammate-teammate relationships. Journal of Management Systems, 3(3): 49-54.

House, R. J. \& Rizzo, J. R. (1972a). Role conflict and ambiguity as critical variables in a model of organizational behavior. Organizational Behavior and Human Performance, 7 (June), 467-505.

House, R. J., \& Rizzo, J. R. (1972b). Toward the measurement of organizational practices: Scale development and validiation. Journal of Applied Psychology, 56, 288-296.

Keller, T., \& Dansereau, F. (1995). Leadership and empowerment: A social exchange perspective. Human Relations, 48, 127-146.

Lagace, R. R., Castleberry, S. B., \& Ridnour, R. E. (1993). An exploratory sales force study of the relationship between leader-member exchange and motivation, role stress, and manager evaluation. Journal of Applied Business Research, 9, 110-119

Liden, R. C.,\&Maslyn, J. M. (1998).Multidimensionality of leader-member exchange:An empirical assessment through scale development. Journal of Management, 24, 43-72.

Major, D. A., Kozlowski, S. W. J., Chao, G. T., \& Gardner, P. D. (1995). A longitudinal investigation of newcomer expectations, early socialization outcomes, and the moderating effects of role development factors. Journal of Applied Psychology, 80, 418-431

Mardanov, I., Sterrett, J., Baker, J. (2007). Satisfaction with Supervision and Member Job Satisfaction in Leader-Member Exchange: An Emprical Study in the Restaurant Industry. Journal of Applied Management and Entrepreneurship,12, 3.

Nystrom, P.C. (1990). Organizational commitment. Group \& Organization Studies, 5,296-312. 
Pond, S.B., and Geyer, P.D. (1991) Differences in the relation between job satisfaction and perceived work alternatives among older and younger blue-collar workers. Journal of Vocational Behavior, 39: $251-262$

Quinn, R. P., and Shepard, L. J. (1974) The 1972-73 Quality of Employment Survey, Ann Arbor, MI: Institute for Social Research.

Scandura, T.A., Graen, G.B., \& Novak, M.A. (1986). When managers decide not to decide autocratically. Journal of Applied Psychology, 71, 106

Schyns, B., \& Croon, M. A. (2006). A model of task demands, social structure, and leader-member exchange and their relationship to job satisfaction. International Journal of Human Resource Management, 17, 602-615.

Seers, A., \& Graen, G. B. (1984). The dual attachment concept: A longitudinal investigation of the combination of task characteristics and leader-member exchange. Organizational Behavior and Human Performance, 33, 283-306.

Snyder, R. A., \& Bruning, N. S. (1985). Quality of vertical dyad linkages: Congruence of supervisor and subordinate competence and role stress as explanatory variables. Group and Organization Studies, 10, 81-94

Sparrowe, R. T., \& Liden, R. C. (1997). Process and structure in leader-member exchange. Academy of Management Review, 22, 522-552

Tepper,B.J. (2000).Consequences of abusive supervision. Academy of Management Journal, 43, p. 178-190.

Thamos, C.H., Lankau, M.J. (2009). Preventing burnout: the effects of LMX and mentoring on socialization, role stress and burnout. Human Resource Management, 48(3), 417-432.

Wilhelm, C.C., Herd, A.M., \& Steiner, D.D. (1993). Attributional conflict between managers and subordinates: An investigation of leader-member exchange effects. Journal of Organizational Behavior, 14, 531-544. 